\title{
PALEOANTHROPOLOGICAL CHARACTERISTICS OF THE EARLY SARMATIAN POPULATION OF EMBA BASIN RIVER ACCORDING TO THE DATA FROM MORTYK I CEMETERY
}

\author{
Egor P. Kitov \\ Institute of Ethnology and Anthropology of the Russian Academy of Sciences, Moscow, Russian Federation; \\ Institute of Archaeology named after A.Kh. Margulan, Almaty, Republic of Kazakhstan

\section{Artem P. Grigorev} \\ Volga-Ural Center for Paleoanthropological Research of the Samara State Social and Pedagogical University, \\ Samara, Russian Federation
}

\begin{abstract}
The paper focuses on the anthropological materials obtained from the cemetery Mortyk I. This archaeological monument is located on the Emba River, which originates from the western slopes of Mugodzhar mountains and flows into the Caspian Sea. Today it is one of the southernmost studied Sauromat-Sarmatian monuments of the early nomads. Unfortunately, there are practically no studied cemeteries dating back to the VIIV centuries BC located in this region, despite the large number of cemeteries in this region and the Northern Aral Sea region. Anthropological materials from Mortyk I cemetery were studied using the craniological and osteometric programs, comonnly used in Russian science. A statistical and individual typological analysis was performed due to small number of series and their satisfactory preservation. According to the results of the analysis, the presented series shows the closest analogies with the population of the Ural river basin of the end of VI-IV centuries BC, despite the small number of individuals. Moreover, it can be noted that the Mortyk I archaeological monument appears to be the part of the general array of Sauromat-Sarmatian monuments, which occupies not only the Ural river basin and the Ustyurt plateau, but also the region to the north of the Aral Sea. It can be assumed that forming of culture and physical characteristics shown by the early nomads of the Sauromat-Sarmatian appearance connects them with the territory of the Aral Sea region and the Southern Ural. Further study of the monuments in the arid territories of the Northern Aral Sea region will reveal a lot of answers to debatable questions about the early nomads of the Volga-Ural region and Western Kazakhstan and origin and genesis of their culture and appearance.

Key words: early nomads, Sauromatians, Sarmatians, Southern Urals, Western Kazakhstan, anthropology, archaeology.
\end{abstract}

Citation. Kitov E.P., Grigorev A.P., 2020. Paleoanthropological Characteristics of the Early Sarmatian Population of Emba Basin River According to the Data from Mortyk I Cemetery. The Lower Volga Archaeological Bulletin, vol. 19, no. 1, pp. 130-148. (in Russian). DOI: https://doi.org/10.15688/nav.jvolsu.2020.1.7

\section{ПАЛЕОАНТРОПОЛОГИЧЕСКАЯ ХАРАКТЕРИСТИКА РАННЕСАРМАТСКОГО НАСЕЛЕНИЯ БАССЕЙНА РЕКИ ЭМБА ПО ДАННЫМ ИЗ МОГИЛЬНИКА МОРТЫК І}

\section{Егор Петрович Китов}

Институт этнологии и антропологии им. Н.Н. Миклухо-Маклая РАН, г. Москва, Российская Федерация;

Институт археологии им. А.Х. Маргулана МОН РК, г. Алматы, Республика Казахстан 


\section{Артем Петрович Григорьев}

Самарский государственный социально-педагогический университет, г. Самара, Российская Федерация

Аннотация. В работе представлены антропологические материалы из могильника Мортык I. Памятник находится на р. Эмба, которая берет свое начало от западных склонов Мугоджар и впадает в Каспийское море. В настоящее время это один из самых южных изученных савромато-сарматских памятников ранних кочевников. К сожалению, мы практически не знаем исследованных могильников VI-IV вв. до н.э. в данном регионе, несмотря на большое количество курганных могильников в данном регионе и Северном Приаралье. Антропологические материалы из могильника Мортык I были изучены по краниологической и остеометрическим программам, использованным в отечественной науке. Был проведен статистический и индивидуально-типологический анализ в связи с небольшой численностью серий и удовлетворительной их сохранностью. По итогам анализа, несмотря на небольшую численность индивидов, представленная серия находит ближайшие аналогии с населением бассейна реки Урал конца VI-IV вв. до н.э. По результатам анализа можно отметить, что памятник Мортык I входит в общий массив савромато-сарматских памятников, которые занимают не только бассейн р. Урал и плато Устюрт, но и регион на севере от Аральского моря. Можно предположить, что ранние кочевники савромато-сарматского облика связаны формированием культуры и физических особенностей с территорией Приаралья и Южного Урала. Дальнейшее исследование памятников на аридных территориях Северного Приаралья позволит открыть немало ответов на дискуссионные вопросы, связанные с происхождением и генезисом культуры и облика ранних кочевников Волго-Уральского региона и Западного Казахстана.

Ключевые слова: ранние кочевники, савроматы, сарматы, Южное Приуралье, Западный Казахстан, антропология, археология.

Цитирование. Китов Е. П., Григорьев А. П., 2020. Палеоантропологическая характеристика раннесарматского населения бассейна реки Эмба по данным из могильника Мортык I / Нижневолжский археологический вестник. Т. 19, № 1. C. 130-148. DOI: https://doi.org/10.15688/nav.jvolsu.2020.1.7

Могильник Мортык I находится на р. Эмба, в 4 км от населенного пункта Шенгельши Актюбинской области Республики Казахстан. Был исследован Актюбинской археологической экспедицией Института археологии им. А.Х. Маргулана под руководством Ж.Е. Смаилова и Б.А. Книсарина в 2004 году. Могильник датируется концом VI - IV в. до н.э. и относится к савромато-сарматским погребальным памятникам раннего железного века (далее - РЖВ) Западного Казахстана [Смаилов и др., 2005].

Обработка антропологических коллекций по краниометрической и остеологическим программам проводилась в 2007 году. Серия представлена 10 индивидами, половозрастные определения даны в таблице 1 .

Целью работы является введение полученных данных в научный оборот и сравнение полученных результатов на фоне серий кочевников для выяснения вопросов происхождения населения, представляющего самый южный памятник РЖВ на территории Актюбинской области.

В результате исследования костные материалы были изучены по краниометричес- кой и остеометрической программам. Краниометрическая характеристика была проведена с применением методики В.П. Алексеева и Г.Ф. Дебеца [Алексеев, Дебец, 1964]. Для межгруппового канонического анализа краниологических серий использовалась программа И.А. Гончарова Multican [Гончаров, Гончарова, 2016] и пакет статистических программ Statistica 12. Также была выполнена статистическая оценка межгруппового сходства путем вычисления квадратов расстояния Махаланобиса с поправкой на численность.

Посткраниальный скелет был охарактеризован на индивидуальном уровне по размерным рубрикациям продольных остеологических размеров [Мамонова, 1986; Пежемский, 2011], а также опираясь на оценочную программу фиксации степени развития мест крепления мышц на костях [Медникова, 1998]. Кроме того, производилась фиксация патологических изменений и травм на скелетных останках при использовании в качестве консультации классических работ по этой тематике [Рохлин, 1965; Бужилова, 2005]. 
Краниологическая характеристика. Мужская серия представлена четырьмя черепами удовлетворительной сохранности (табл. 4). Черепная коробка средневысокая, брахикранная, имеет большую длину и ширину. Лоб среднеширокий по наименьшей и широкий по наибольшей ширине, слабонаклонный. Лицевой отдел высокий, очень широкий на верхнем и среднеширокий на среднем уровне и по скуловому диаметру. Орбиты очень широкие, низкие, мезоконхные. Нос узкий, средневысокий, лепторинный. Носовые кости среднеширокие, высокие, визуально в профиль выступают сильно. Горизонтальная профилировка незначительно уплощена на обоих уровнях, мезогнатная при прогнатной части лицевого отдела. В целом серия визуально однородная, представляет собой европеоидные черепа с примесью монголоидности (уралоидная составляющая).

Женская выборка представлена тремя черепами хорошей сохранности (табл. 5). Черепная коробка средневысокая, средней длины и ширины, по указателю мезокранная. Лоб широкий по наименьшей и наибольшей ширине, слабонаклонный. Лицевой отдел по высоте и ширине на верхнем уровне находится на границе средних и больших размеров, среднеширокий на нижнем уровне и по скуловому диаметру. Горизонтальная профилировка уплощенная на верхнем и резкая на нижнем уровнях. По вертикали мезогнатная при прогнатной альвеолярной части. Орбиты широкие и низкие, по указателю хамэконхные. Носовые кости среднеширокие, очень высокие, по указателю лепторинные, в профиль выступают сильно (за исключением черепа из кург. 4, погр. 1, у которого угол выступания носа в профиль слабый). Черепа в целом имеют сходные характеристики, кроме индивида из кург. 4, погр.1, краниум которого относительно грацильный.

Мужские и женские черепа имеют в целом сходный набор признаков и морфологических характеристик. К сожалению, мужские мозговые капсулы не очень хорошей сохранности. Женские краниумы, несмотря на то, что представлены небольшим количеством, более пригодны для статистического анализа. В связи с тем, что географически расположение могильника, откуда происходят антропологические материалы, находится на южной периферии ареала исследованных памятников савромато-сарматского облика, актуальным является выявление направления этногенетических связей населения бассейна p. Эмба. Для решения данной задачи было проведено сравнение женской серии на широком фоне синхронных групп Центральной Азии и степной полосы Евразии. Для сравнения были выбраны серии раннего железного века, представленные в таблице 2.

Результаты канонического анализа с использованием краниологической серии из могильника Мортык I на фоне серий синхронного времени представлены на рисунке 1 . Первые две компоненты отразили в результате 72,1 \% общей изменчивости (табл. 3). Максимальные нагрузки по КВ I получили продольный диаметр, наименьшая ширина лба и угол выступания носа. Более короткая черепная коробка с узким лбом, сочетается со слабым углом выступания носа. По КВ ІІ в положительной зоне находятся черепа, имеющие узкую черепную коробку, большую высоту носа и низкое значение SS/SC.

Рассматривая результаты анализа женских серий, можно отметить, что в зоне нулевых и положительных значений КВ I находится большинство серий из Центральной Азии, Южной Сибири и Волго-Уралья - это антропологически смешанные серии, имеющие, как отмечается всеми исследователями, в различной степени монголоидную примесь [Чикишева, 2012, Рыкун, 2013; Китов, Мамедов, 2014; Бейсенов и др., 2015; Китов и др., 2019 и др.]. В зоне отрицательных значений находятся европеоидные серии, причем саки Памира занимают самое крайнее положение из-за средиземноморского облика. Также в той же зоне располагаются серии скифов Причерноморья, тагарской культуры, Чауху 4, саков Алая. По КВ II в зоне нулевых и отрицательных значений находятся черепа смешанного облика с примесью монголоидности, имеющие относительно широкую черепную коробку, низкое лицо и, соответственно, низкий нос. Основной вектор, который делит на европеоидные и монголоидные характеристики - КВ І. Так, заведомо европеоидные серии находятся в зоне отрицательных величин, а монголоидная серия из Каюэ в правом поле графика, при- 
чем обе серии имеют узкие черепные коробки и высокие носовые кости.

Серия Мортык I находится в зоне отрицательных величин, при этом наибольшую близость имеет с группами ранних сармат бассейна р. Урал Западного Казахстана VIIV $(2,9)$ и IV-III $(5,9)^{1}$ вв. до н.э. Наименьшее расстояние фиксируется с серией VIIV вв. до н.э., несмотря на визуальное расстояние между сериями на графике. Относительную близость серия из Мортык I демонстрирует с выборками каменской культуры и могильника Кызылтан $(4,8)$ с территории Павлодарского Прииртышья $(5,9)$, подобную близость можно объяснить общим направлением контактов с лесным населением. В целом сарматские группы обнаруживают определенную близость к сакским группам Центральной Азии, но при этом находятся на периферии графика. Подобное расположение серий можно объяснить тем, что сакские группы Приаралья играли непосредственное участие при сложении физического облика ранних кочевников Западного Казахстана и Волго-Уралья на ранних этапах РЖВ. Также у групп сакского облика и савромато-сарматских популяций имеется общий вектор смешения с населением лесной и лесостепной полосы уралоидного облика. Таким образом, надо отметить, что серия из могильника Мортык I имеет общую генетическую основу с ранними сарматами бассейна р. Урал, что подтверждается близостью и материальной культуры, и традиций для савромато-сарматских групп.

Остеологический анализ. Серия могильника Мортык I и V представлена семью индивидами с завершенным процессом роста (четыре мужских и три женских) и одним скелетом человека ювенильного возраста (табл. 6). Индивидуальные остеометрические признаки представлены в таблице 3 .

Мужская серия

Мортык I, курган 1. Длинные кости предплечья мужчины, расчищенные в заполнении погр. 1, имеют очень большие размеры. Ключица, принадлежащая, вероятно, тому же индивиду, средней длины. Эти элементы скелета не имеют заметных патологических деформаций. Костный рельеф выражен средне.

Погребение 2, курган 1. Плечевые кости визуально крупные, их длина была не менее
350 мм. Данный размер предполагается с учетом обломанного верхнего эпифиза. Лучевые и локтевые кости большой длины, в ту же размерную категорию попадает и длина ключицы. Бедренные и парные берцовые кости очень большие. По-видимому, на данном скелете наблюдается увеличение длины дистальных сегментов конечностей, особенно заметное в верхнем отделе. Очевидна условная массивность данного скелета - полученный показатель УПОС Г.Ф. Дебеца [Дебец, 1964] довольно высок. На костях следов патологий не зафиксировано, особенностей в развитии мест креплений мышц не имеется, в целом они могут быть охарактеризованы 1,5-2 баллами.

Мортык I, курган 2. Продольные размеры длинных костей этого скелета средние либо выше средних величин. Пропорционально этот индивид имеет сбалансированное сложение согласно остеометрическим указателям. Примечательны следующие особенности развития опорно-двигательного аппарата. В первую очередь очевиден сильно выраженный рельеф в местах крепления мышц, особенно в области ягодичной бугристости и шероховатой линии бедренной кости, дельтовидной бугристости и малого бугорка плечевой кости, оцениваемых в 2,5-3 балла. Тела позвонков Th11 и Th12 имеют сильные краевые костные разрастания (остеофиты), но таких деформаций в поясничном отделе не наблюдается. Эти особенности могут свидетельствовать о некоторой возможной специализации в деятельности данного индивида. Подобные признаки ранее включались в остеологический комплекс всадника [Бужилова, 2008; Ражев, 1996; 2009 и др.]. Кроме того, на обеих локтевых костях наблюдаются следы зажившего перелома дистальной трети диафизов.

Мортык I, курган 3, погребение 1. Имеющиеся кости верхнего пояса конечностей имеют большую длину, равно как и дистальные сегменты нижней конечности, а бедренная кость ранжируется средним размером. Отметим сильно выраженное относительное удлинение дистального отдела нижней конечности. Кости данного индивида также отмечаются сильно выраженным рельефом на плечевых и предплечевых костях. Трехбалловой оценкой удостоены места креплений мышц на большеберцовых костях. 
Женская серия

Женский скелет из погребения 1 кургана 1. Все длинные кости скелета имеют средние размеры. Фиксируется относительное увеличение голени за счет бедра.

Женский скелет из погребения 1 кургана 4. Кости рук средней длины, ключицы малые. Бедренные кости средней длины, но их размеры близки к малым, а дистальный сегмент нижней конечности среднего размера. Это заметно и по показателю берцово-бедренного указателя, попадающего в категорию «большой».

Скелет, принадлежащий женщине, из погр. 2 кург. 4 несколько отличается от остальных. По реконструируемой длине тела, и по продольным параметрам длинных костей он вполне схож с остальными. При этом его пропорциональные опции заметно отличаются относительной укороченностью голени.

Визуально по остеометрическим показателям мужские скелеты морфологически близки. Женские скелеты по тотальным размерам также морфологически идентичны, что подтверждается и по стандартным отклонениям, несмотря на небольшие численности. Наблюдается тенденция к удлинению дистальных сегментов конечностей. Выделяется мужской скелет из погр. 2 кург. 1 повышенными продольными показателями. Учитывая краниологическую однородность группы, это обстоятельство можно объяснить индивидуальной изменчивостью. Опубликованных данных для сравнения остеометрических характеристик по савромато-сарматским сериям, к сожалению, немного. Так, в серии могильника сарматской культуры Южного Приуралья Прохоровка I также выделяются мужские скелеты с отчетливой гиперморфией сложения. Связывается это с наличием «чужеродного элемента» в составе однородной группы людей, оставившей могильник [Фризен, 2010 , c. 313]. Остается не совсем ясным, что подразумевает автор, констатируя относительную однородность выборки при повышенной изменчивости посткраниального скелета. Обращаясь к материалам савромато-сарматского времени Покровского микрорайона в Южном Приуралье, можно отметить, что сравнение группы Мортыка I возможно только по остеометрическим индексам, абсолют- ные признаки опубликованы не были. По серии сделан вывод о пропорциональном сложении ранних кочевников из Покровского микрорайона [Фризен, 2011, с. 278]. Тем не менее по имеющимся данным можно отметить возможную схожесть физических особенностей посткраниального скелета нашей серии и представленных в публикации. При этом сравнительный анализ осложнен тем, что ряд параметров рассчитан с ошибками, что сказывается на возможности сравнения.

Только один мужской скелет выделяется из общей серии отчетливым развитием мускульной системы. Обозначенный комплекс характеристик мы склонны связывать со всадничеством. Ранее высказывался тезис о распространении верховой езды в социально обособленной части сарматского общества [Григорьев, Купцова, 2020, с. 135-142]. Эта гипотеза подтверждается результатами исследования антропологических материалов курганного могильника Мортык I.

Таким образом, можно отметить, что представленная нами серия достаточно однородна как по краниологическим, так и по остеометрическим характеристикам. Несмотря на небольшую численность выборки, население, представленное в могильнике Мортык I, вероятнее всего, имеет общие морфологические особенности с сериями из могильников достаточно большого региона Западного Казахстана и Волго-Уралья. Река Эмба, на берегу которой находится могильник, течет от западных склонов Мугоджар до Каспийского моря. К сожалению, в настоящий момент практически неизвестны изученные савромато-сарматские памятники с территории данного региона, несмотря на их большую плотность в Северном Приаралье и Южном Приуралье. По результатам как статистического, так и визуально-типологического анализа можно отметить, что могильник Мортык I входит в общий массив савромато-сарматских памятников, которые занимают не только бассейн р. Урал и Устюрт, но и Южное Приуралье и Северное Приаралье.

\section{ПРИМЕЧАНИЕ}

${ }^{1}$ В скобках даны расстояния Махаланобиса с поправкой на численность. 


\section{ИЛЛЮСТРАЦИИ}

\section{Таблица 1. Половозрастные определения индивидов из могильника Мортык I}

Table 1. Gender and age definitions of Mortyk I burial ground

\begin{tabular}{|c|l|l|l|c|}
\hline № п/п & Могильник & \multicolumn{1}{|c|}{ Курган / погребение } & Пол & Возраст \\
\hline 1 & Мортык I & кург. 1, погр. 1, западн. скел. & жен. & $25-35$ \\
\hline 2 & Мортык V & кург. 1, погр. 1, вост. скел. & муж. & $40-45$ \\
\hline 3 & Мортык I & кург. 1, погр. 1, заполнение & муж. & $35-45$ \\
\hline 4 & Мортык I & кург. 1, погр. 2 & муж. & $35-45$ \\
\hline 5 & Мортык I & кург. 2 & муж. & $35-45$ \\
\hline 6 & Мортык I & кург. 3, погр. 1 & муж. & $35-45$ \\
\hline 7 & Мортык I & кург. 3, погр. 1, восточн. скел. & муж. & $35-45$ \\
\hline 8 & Мортык I & кург. 3, погр. 2 & - & 11 \\
\hline 9 & Мортык I & кург. 4, погр. 1, нижн. скел. & жен. & $25-35$ \\
\hline 10 & Мортык I & $\begin{array}{l}\text { кург. 4, погр. 2, втор. ярус, } \\
\text { северн. скел. }\end{array}$ & жен. & $35-45$ \\
\hline
\end{tabular}

\section{Таблица 2. Женские серии ранних кочевников, использованные в анализе}

\section{Table 2. Women's series of early nomads used in the analysis}

\begin{tabular}{|c|c|c|}
\hline Серии & Территория & Авторы \\
\hline Саки Притяншанья (суммарно) & Прит яншанье & [Китов и др., 2019] \\
\hline Аймырлыг XXXI (III-I вв. до н.э.) & Тува & [Богданова, Радзюн, 1991] \\
\hline $\begin{array}{l}\text { Аржан II / ранний этап алды- } \\
\text { бельской культуры }\end{array}$ & Тува & [Чикишева, 2012] \\
\hline Догээ-Баары II & Тува & [Чикишева, 2008] \\
\hline Каменская культура & Южная Сибирь & [Рыкун, 2013] \\
\hline Каракобинские погребения & Горный Алтай & [Чикишева 2003] \\
\hline $\begin{array}{l}\text { Копто / ранний этап алды- } \\
\text { бельской культуры }\end{array}$ & Тува & [Чикишева, 2008] \\
\hline Коргантасский тип памятников & Центральный Казахстан & $\begin{array}{l}\text { [Китов, Бейсенов, 2015; Бейсенов и др., } \\
\text { 2015; Beisenov, Kitov, 2015] }\end{array}$ \\
\hline Кызылтан (Северный Казахстан) & Павлодарское Прииртышье & Китов, неопубликованные данные \\
\hline Пазырыкская культура & Горный Алтай & [Чикишева, 2003] \\
\hline Саки Алая & Южная Киргизия & [Китов, Тур, Иванов, 2019] \\
\hline Саки Восточного Казахстана & Северо-Восточный Казахстан & [Гинзбург, 1956; 1961] \\
\hline Саки Юго-Восточного Памира & Таджикистан & [Гинзбург, Трофимова, 1972] \\
\hline $\begin{array}{l}\text { Саки Нижней Сырдарьи (Тагискен } \\
\text { и Уйгарак) }\end{array}$ & Восточное Приаралье & [Итина, Яблонский, 1997] \\
\hline Саки Приаралья & Восточное Приаралье & [Трофимова, 1963] \\
\hline Саргатская культура & Южная Сибирь & [Багашев, 2000; 2017] \\
\hline $\begin{array}{l}\text { Сарматы Западного Казахстана } \\
\text { (IV-III вв. до н.э.) }\end{array}$ & $\begin{array}{l}\text { Волго-Уральский регион и Запад- } \\
\text { ный Казахстан }\end{array}$ & [Китов, Мамедов, 2014] \\
\hline $\begin{array}{l}\text { Сарматы Западного Казахстана } \\
\text { (V-IV вв. до н.э.) }\end{array}$ & $\begin{array}{l}\text { Волго-Уральский регион и Запад- } \\
\text { ный Казахстан }\end{array}$ & [Китов, Мамедов, 2014] \\
\hline $\begin{array}{l}\text { Скифы Западной Монголии } \\
\text { (Улангом) }\end{array}$ & Западная Монголия & [Ćikiševa, 2010] \\
\hline Скифы Тувы (сборная серия) & Тува & [Ćikiševa, 2010] \\
\hline Тагарская культура & Минусинская котловина & [Козинцев, 1977] \\
\hline Тасмолинская культура & Центральный Казахстан & $\begin{array}{l}\text { [Бейсенов и др., 2015; Бейсенов, Китов, } \\
\text { 2014] }\end{array}$ \\
\hline Чayxy 4 & Центральный Синьцзян & [Синьцзян Чауху, 1999] \\
\hline Алагоу & Синьцзян // Турфанская котловина & [Хань Кансинь, 1993; 2010] \\
\hline Чжаосу & Синьцзян // бассейн р.Или & [Хань Кансинь, 1993; 2010] \\
\hline Янбулак & Синьцзян / Хами & [Хань Кансинь, 1993; 2010] \\
\hline Каюэ & Профинция Цинхай, Китай & [Хань Кансинь и др., 2005] \\
\hline Скифы Причерноморья & Нижнее Поднепровье & [Кондукторова, 1972] \\
\hline Скифы Николаевка & Поднепровье & [Великанова, 1975] \\
\hline Скифы Никополь & Поднепровье & [Зиневич, 1967] \\
\hline Мортык I (кон. VI - IV вв. до н.э.) & Приуралье & Материалы авторов \\
\hline
\end{tabular}




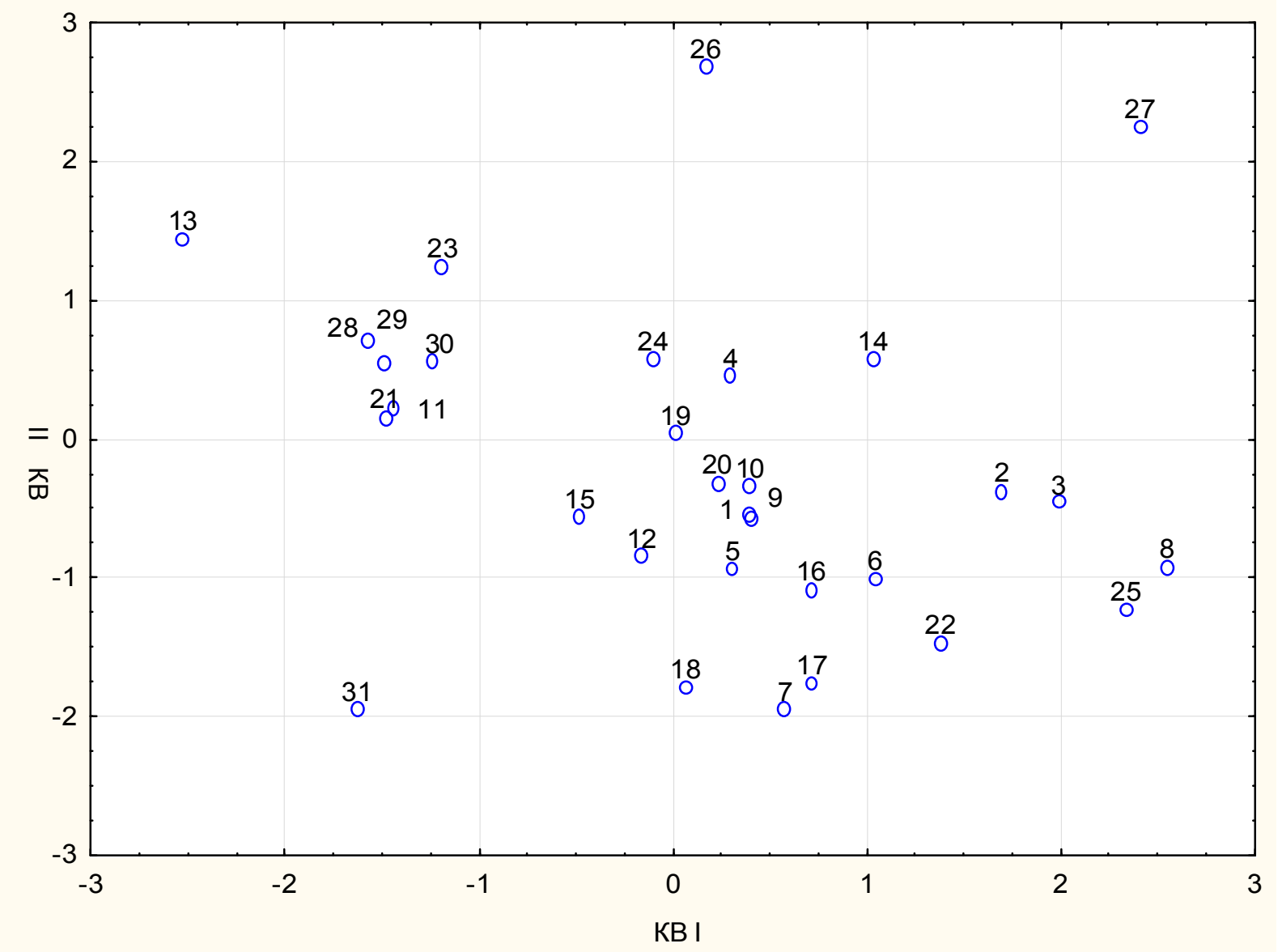

Рис. 1. Расположение женских серий в пространстве I и II КВ:

1 - Саки Притяньшанья (суммарно); 2 - Аймырлыг XXXI (III-I вв. до н.э.); 3 - Аржан II; 4 - Догээ-Баары II; 5 - Каменская культура; 6 - Каракобинские погребения; 7 - Копто; 8 - Коргантасский тип памятников; 9 - Кызылтан (Северный Казахстан); 10 - Пазырыкская культура; 11 - Саки Алая; 12 - Саки Восточного Казахстана; 13 - Саки Юго-Восточного Памира; 14 - Саки Нижней Сырдарьи (Тагискен и Уйгарак); 15 - Саки Приаралья; 16 - Саргатская культура; 17 - Сарматы Западного Казахстана (IV-III вв. до н.э.);

18 - Сарматы Западного Казахстана (VI-IV вв. до н.э.); 19 - Скифы Западной Монголии (Улангом); 20 - Скифы Тувы (сборная серия); 21 - Тагарская культура; 22 - Тасмолинская культура; 23 - Чауху IV; 24 - Алагоу; 25 - Чжаосу; 26 - Янбулак; 27 - Каюэ; 28 - Скифы Причерноморья; 29 - Скифы Николаевка; 30 - Скифы Никополь; 31 - Мортык I

Fig. 1. Location of female series in the space of I-th and II-d canonical vectors:

1 - Saka culture of Tien-Shan (summary); 2 - Aymyrlyg XXXI (III-I cc. BC); 3 - Arzhan II; 4 - Dogee-Baary II; 5 - Kamenskaya culture; 6 - Karakobinsk type; 7 - Kopto; 8 - Korgantas type;

9 - Kyzyltan (Northern Kazakhstan); 10 - Pazyryk culture; 11 - Saka culture (Alay); 12 - Saka culture (Eastern Kazakhstan); 13 - Saka culture (Pamir); 14 - Saka culture (Tagisken i Uygarak); 15 - Saka culture (Aral region); 16 - Sargat culture; 17 - Sarmatians of Western Kazakhstan (IV-III cc. BC);

18 - Sarmatians of Western Kazakhstan (VI-IV cc. BC); 19 - Scythians of Western Mongolia (Ulangom); 20 - Scythians of Tuva (summary); 21 - Tagar cultur; 22 - Tasmola culture; 23 - Chaukhu IV;

24 - Alagou; 25 - Chzhaosu; 26 - Yanbulak; 27 - Kayue; 28 - Scythians (Nothern Black Sea); 29 - Scythians (Nikolayevka); 30 - Scythians (Nikopol); 31 - Mortyk I 


\section{Таблица 3. Нагрузки на канонические вектора}

Table 3. Factor structure of the canonical analysis

\begin{tabular}{|l|c|c|c|}
\hline \multicolumn{1}{|c|}{ № признака по Мартину } & KB I & KB II & KB III \\
\hline $\mathbf{1}$ & $\mathbf{- 0 . 4 4 8}$ & 0.446 & -0.264 \\
\hline $\mathbf{8}$ & 0.486 & $\mathbf{- 0 . 5 7 4}$ & 0.458 \\
\hline $\mathbf{1 7}$ & 0.064 & 0.380 & -0.075 \\
\hline $\mathbf{9}$ & $\mathbf{- 0 . 7 1 4}$ & -0.173 & 0.068 \\
\hline $\mathbf{4 5}$ & 0.005 & -0.310 & $\mathbf{- 0 . 5 1 6}$ \\
\hline $\mathbf{4 8}$ & -0.092 & -0.279 & $\mathbf{0 . 5 6 9}$ \\
\hline $\mathbf{5 5}$ & 0.357 & $\mathbf{0 . 5 5 9}$ & -0.058 \\
\hline $\mathbf{5 4}$ & 0.169 & 0.141 & 0.457 \\
\hline $\mathbf{5 1}$ & 0.183 & -0.243 & $\mathbf{- 0 . 5 4 9}$ \\
\hline $\mathbf{5 2}$ & 0.042 & 0.248 & 0.244 \\
\hline $\mathbf{7 7}$ & 0.237 & 0.219 & -0.418 \\
\hline $\mathbf{z m}$ & 0.292 & -0.047 & 0.143 \\
\hline SS:SC & -0.092 & $\mathbf{- 0 . 4 5 6}$ & -0.191 \\
\hline $\mathbf{7 5}$ (1) & $\mathbf{- 0 . 5 8 1}$ & 0.135 & 0.398 \\
\hline Собственное значение & 66.32 & 41.98 & 8.79 \\
\hline \% объясняемой изменчивости & 44,2 & 27,9 & 5,9 \\
\hline
\end{tabular}

Таблица 4. Краниологическая характеристика мужских черепов из могильника Мортык I

\section{Table 4. Craniological characteristics of male skulls from the Mortyk I burial ground}

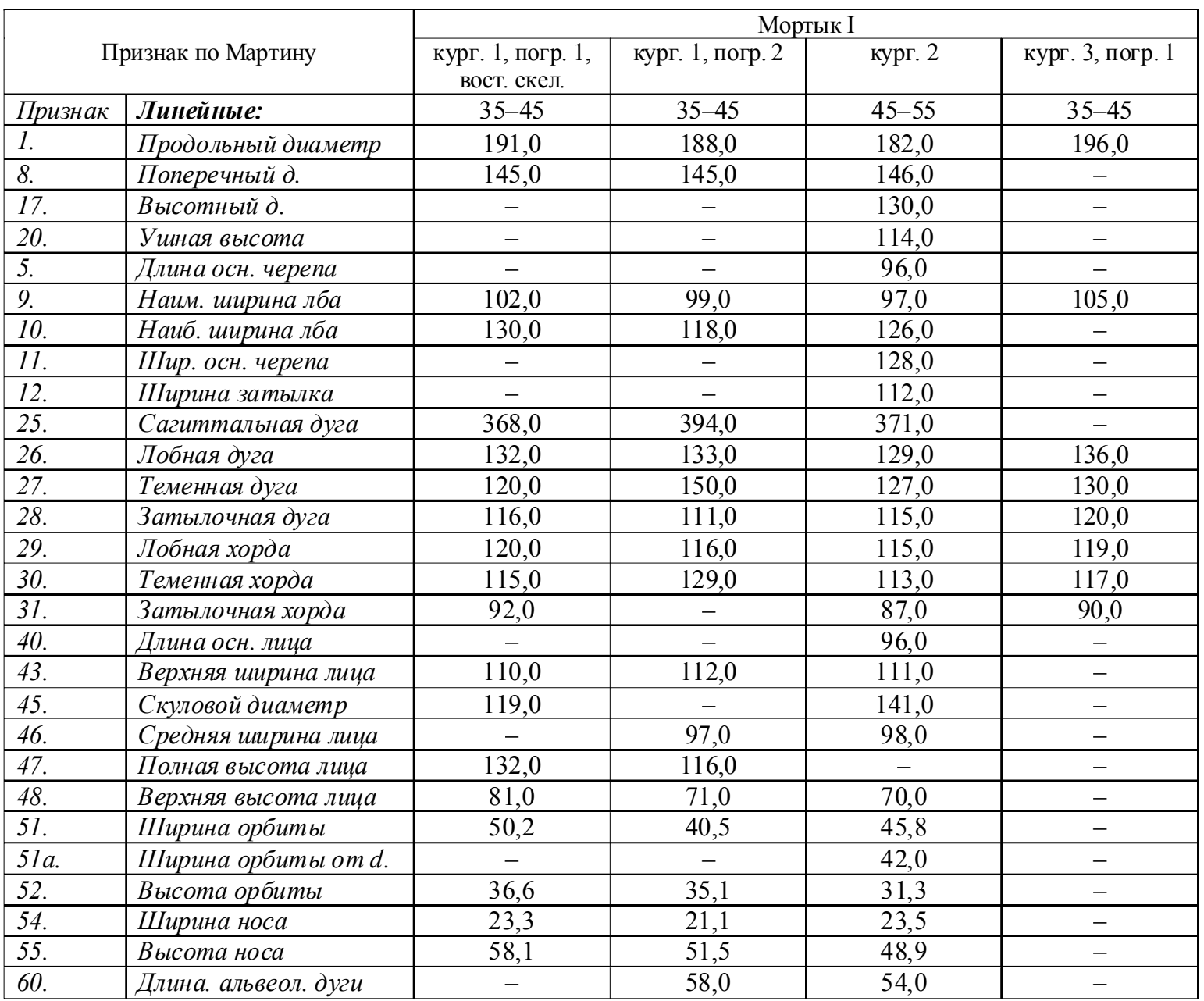


Окончание таблицьь 4

End of Table 4

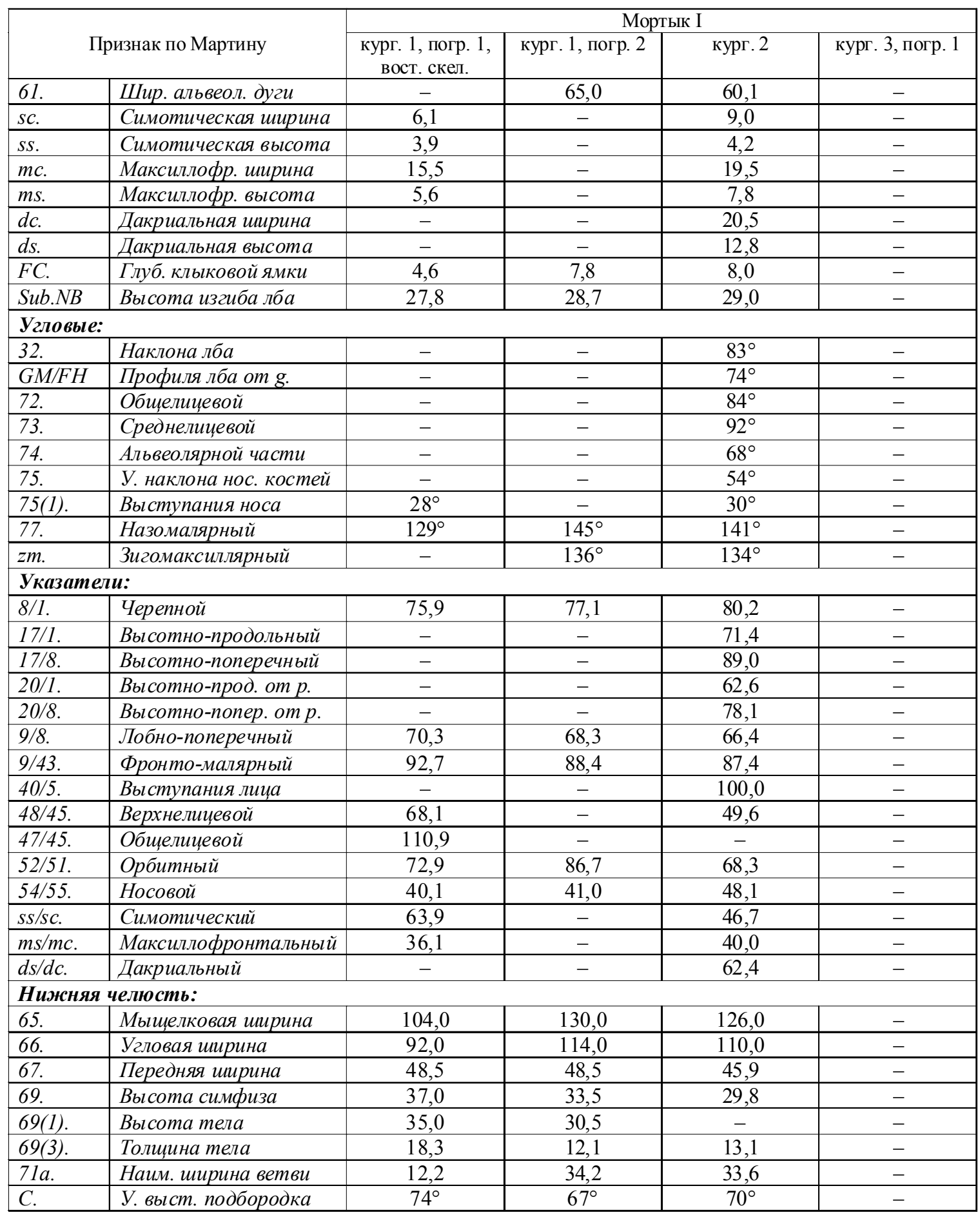


Палеоантропологическая характеристика раннесарматского населения бассейна реки Эмба

Таблица 5. Краниологическая характеристика женских черепов из могильников Мортык I

Table 5. Craniological characteristics of female skulls from the Mortyk I burial ground

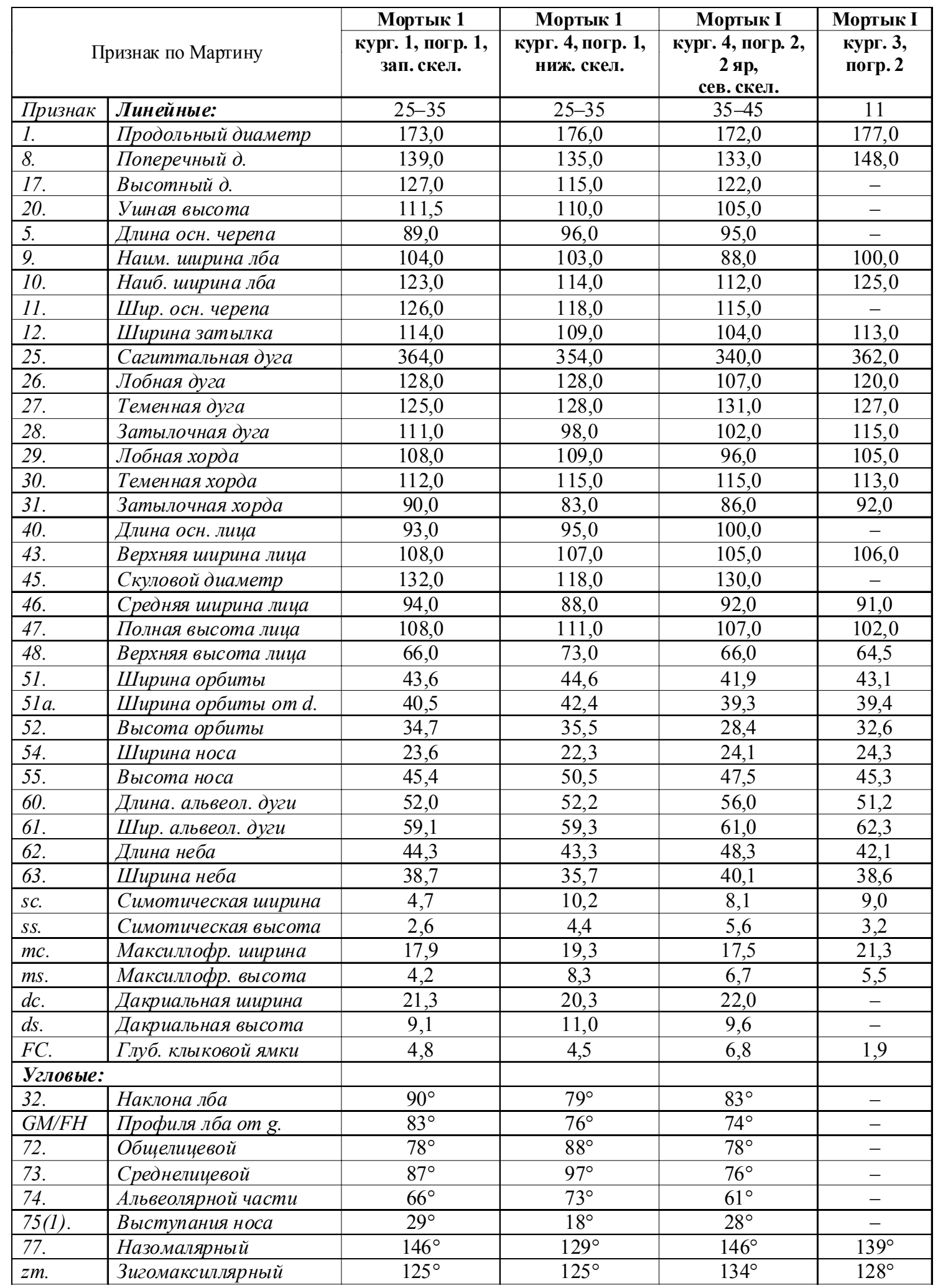


Paleoanthropological Characteristics of the Early Sarmatian Population of Emba Basin River

Окончание таблицы 5

End of Table 5

\begin{tabular}{|c|c|c|c|c|c|}
\hline \multirow{2}{*}{\multicolumn{2}{|c|}{ Признак по Мартину }} & Мортык 1 & Мортык 1 & Мортык I & Мортык I \\
\hline & & $\begin{array}{c}\text { кург. 1, погр. 1, } \\
\text { зап. скел. }\end{array}$ & $\begin{array}{c}\text { кург. 4, погр. 1, } \\
\text { ниж. скел. }\end{array}$ & $\begin{array}{c}\text { кург. 4, погр. } 2, \\
2 \text { яр, } \\
\text { сев. скел. } \\
\end{array}$ & кург. 3, погр. 2 \\
\hline \multicolumn{6}{|c|}{ Указатели: } \\
\hline $8 / 1$. & Черепной & 80,3 & 76,7 & 77,3 & 83,6 \\
\hline $17 / 1$. & Высотно-продольньий & 73,4 & 65,3 & 70,9 & - \\
\hline $17 / 8$. & Высотно-поперечный & 91,4 & 85,2 & 91,7 & - \\
\hline $20 / 1$ & Высотно-прод. от р. & 64,5 & 62,5 & 61,0 & - \\
\hline $20 / 8$. & Высотно-попер. от р. & 80,2 & 81,5 & 78,9 & - \\
\hline 9/8. & Лобно-поперечный & 74,8 & 76,3 & 66,2 & 67,6 \\
\hline 9/43. & Фронто-малярный & 96,3 & 96,3 & 83,8 & 94,3 \\
\hline $40 / 5$. & Выступания лица & 104,5 & 99,0 & 105,3 & - \\
\hline $48 / 45$ & Верхнелицевой & 50,0 & 61,9 & 50,8 & - \\
\hline $52 / 51$. & Орбитныцй & 79,6 & 79,6 & 67,8 & 75,6 \\
\hline $54 / 55$. & Носовой & 52,0 & 44,2 & 50,7 & 53,6 \\
\hline$s S / s c$ & Симотический & 55,3 & 43,1 & 69,1 & 35,6 \\
\hline$m s / m c$. & Максиллофронтальный & 23,5 & 43,0 & 38,3 & 25,8 \\
\hline$d s / d c$ & Дакриальньй & 42,7 & 54,2 & 43,6 & - \\
\hline \multicolumn{6}{|c|}{ Нижняя челюсть: } \\
\hline 65. & Мыцщелковая ширина & 116,0 & 101,0 & - & - \\
\hline 66. & Угловая иирина & 101,0 & 87,5 & - & - \\
\hline 67. & Передняя ширина & 45,0 & 49,1 & 45,3 & - \\
\hline 69. & Выссота симфиза & 32,2 & 29,6 & - & - \\
\hline $69(1)$. & Высота тела & 28,7 & 29,5 & 31,5 & - \\
\hline $69(3)$. & Толщина тела & 11,5 & 11,7 & 11,7 & - \\
\hline $71 a$. & Наим. иирина ветви & 33,1 & 36,0 & 29,7 & - \\
\hline$C$. & У. выст. подбородка & $72^{\circ}$ & $60^{\circ}$ & - & - \\
\hline
\end{tabular}


Палеоантропологическая характеристика раннесарматского населения бассейна реки Эмба

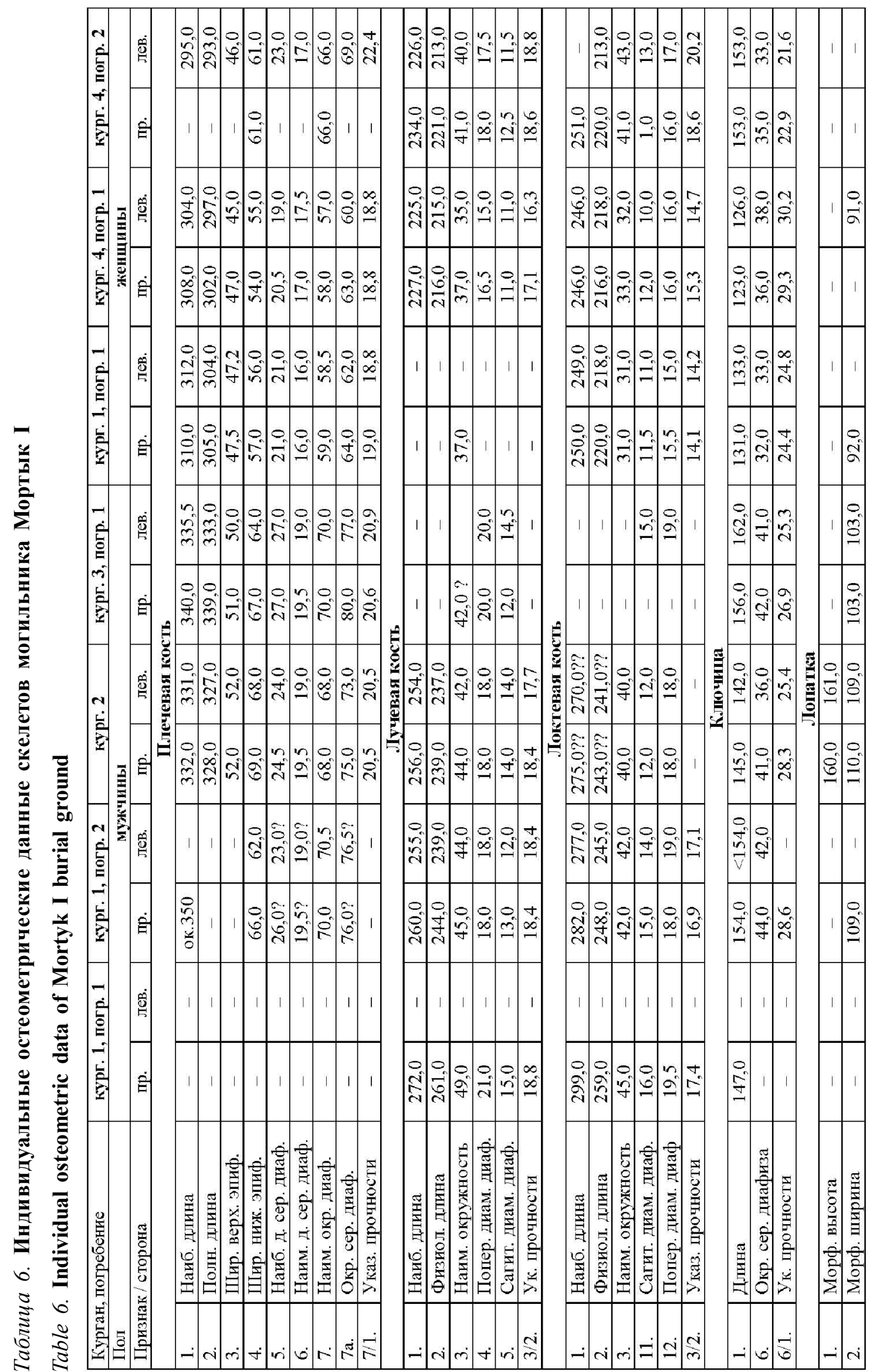


Paleoanthropological Characteristics of the Early Sarmatian Population of Emba Basin River

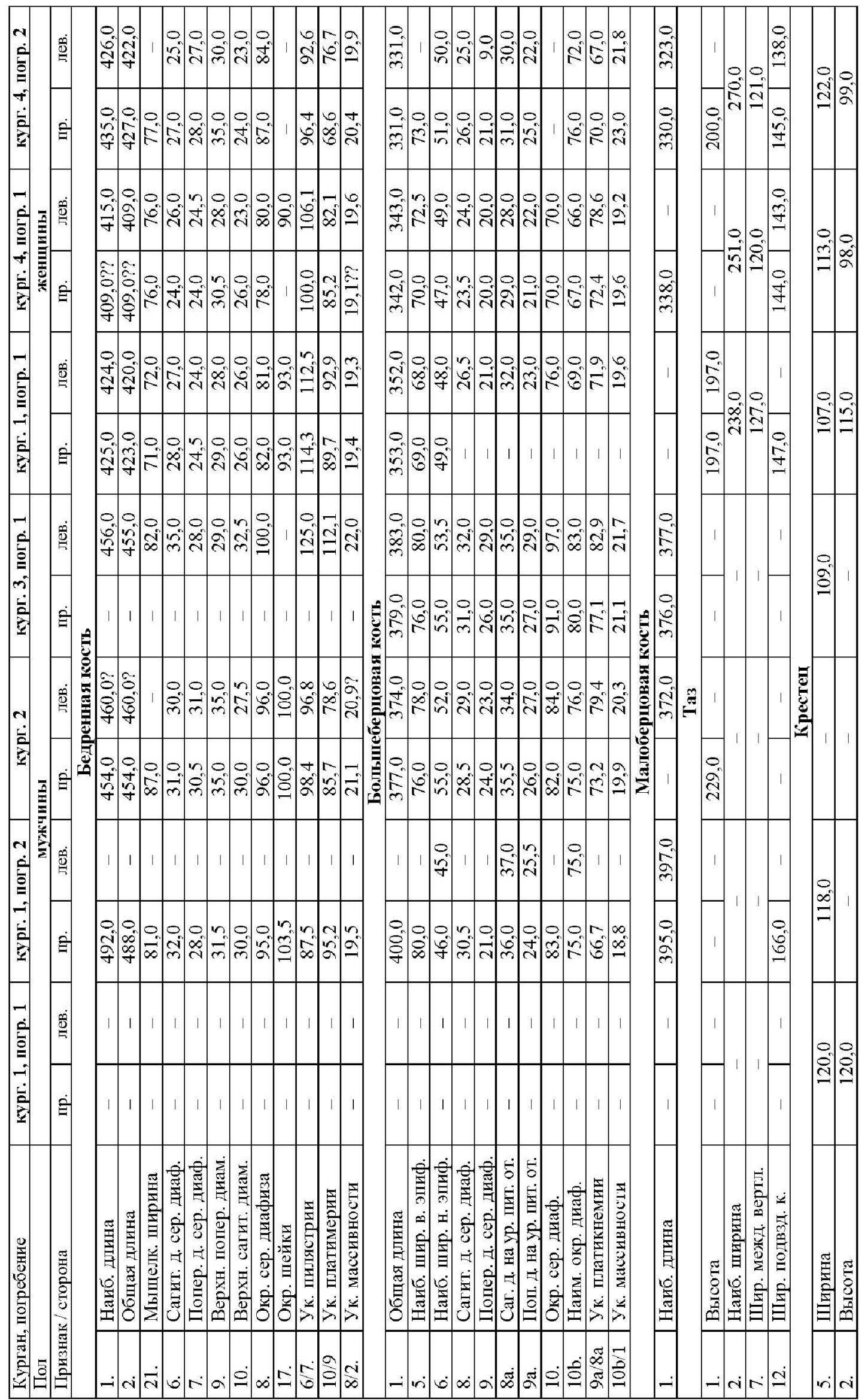


Палеоантропологическая характеристика раннесарматского населения бассейна реки Эмба

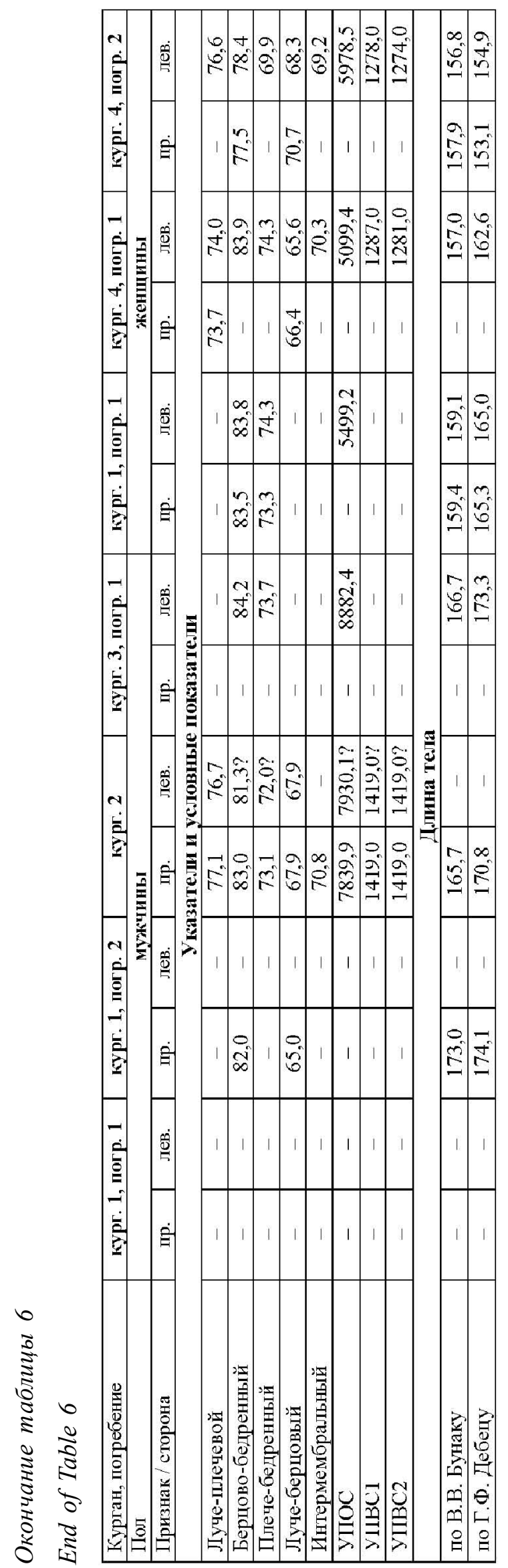




\section{СПИСОК ЛИТЕРАТУРЫ}

Алексеев В. П., Дебец Г. Ф., 1964. Краниометрия: Методика антропологических исследований. М. : Наука. $128 \mathrm{c}$.

Багашев А. Н., 2017. Антропология Западной Сибири. Новосибирск : Наука. 408 с.

Багашев А. Н., 2000. Палеоантропология Западной Сибири: Лесостепь в эпоху раннего железа. Новосибирск : Наука. $374 \mathrm{c}$.

Бейсенов А. З., Исмагулова А. О., Китов Е. П., Китова А. О., 2015. Население Центрального Казахстана в I тысячелетии до н.э. Алматы : Институт археологии им. А.Х. Маргулана. 170 c.

Бейсенов А. 3, Китов Е. П., 2014. Могильник тасмолинской культуры Талды II в Центральном Казахстане (краниологический анализ) // Вестник Волгоградского государственного университета. Серия 4, История, № 4 (28). С. 71-85. DOI: https://dx.doi.org/10.15688/jvolsu4.2014.4.7.

Богданова В. И., Радзюн А. Б., 1991. Палеоантропологические материалы гунно-сарматского времени из Центральной Тувы // Новые коллекции и исследования по антропологии и археологии. Сборник музея антропологии и этнографии. Вып. XLIV. СПб. : Наука. С. 55-100.

Бужилова А. П., 1998. Программа фиксации индикаторов механического стресса, связанного с верховой ездой // Историческая экология человека. Методика биологических исследований. М. : ИА РАН. С. 169-174.

Бужилова А. П., 2005. Нomo sapiens: История болезни. М. : Языки славянской культуры. 320 с.

Бужилова А. П. 2008. К вопросу о распространении традиции верховой езды: анализ антропологических источников // OPUS: Междисциплинарные исследования в археологии. Т. 6. С. 110-120.

Великанова М. С., 1975. Палеоантропология Прутско-Днестровского междуречья. М. : Наука. 284 с.

Гинзбург В. В., 1956. Древнее население Восточных и Центральных районов Казахской ССР по антропологическим данным // Труды ИЭ АН СССР. Т. ХХХІІІ. М. : Изд-во АН СССР. С. 238-298.

Гинзбург В. В., 1961. К антропологии ранних кочевников Восточного Казахстана (черепа V-IV вв. до н.э. из могильника Усть-Буконь) // Антропологический сборник. № 3. М. : Наука. С. 82-97.

Гинзбург В. В., Трофимова Т. А., 1972. Палеоантропология Средней Азии. М. : Наука. 371 с.

Гончаров И. А., Гончарова Н. Н., 2016. Свидетельство о государственной регистрации программы для ЭВМ 2015663150 Российская Федерация. Программа MultiCan для анализа многомерных массивов данных с использованием статистик выборок и параметров генеральной совокупности (MultiCan). № 2016610803 ; заявл. 24.11.2015 ; опубл. 19.01.2016. 1 с.

Григорьев А. П., Купцова Л. В., 2020. Антропологические материалы раннего железного века из курганного могильника у с. Самородово в Оренбуржье // Маргулановские чтения - 2020 : материалы Междунар. археол. науч.-практ. конф. Алматы : Хикари. С. 135-142.

Дебец Г. Ф., 1964. Опыт определения веса живых людей по размерам длинных костей // Труды VII Международного конгресса антропологических и этнографических наук. М. : Наука. $11 \mathrm{c}$.

Зиневич Г. П., 1967. Очерки палеоантропологии Украины. Киев : Наукова Думка. 240 с.

Итина М. А., Яблонский Л. Т., 1997. Саки нижней Сырдарьи (по материалам могильника Южный Тагискен). М. : РОССПЭН. $187 \mathrm{c}$.

Китов Е. П., Бейсенов А. 3., 2015. Первые краниологические данные памятников коргантасского типа Центрального Казахстана // Вестник Челябинского государственного университета. История. Вып. 64. № 14 (369). C. 16-28.

Китов Е. П., Мамедов А. М., 2014. Кочевое население Западного Казахстана в раннем железном веке. Астана : Издательская группа ФИА им. А.Х. Маргулана в г. Астана. 352 c.

Китов Е. П., Тур С. С., Иванов С. С., 2019. Палеоантропология сакских культур Притяншанья (VIII - 1-я половина ІІ в. до н.э.). Алматы : Хикари. 300 с.

Козинцев А. Г., 1977. Антропологический состав и происхождение населения тагарской культуры. Л. : Наука. 142 c.

Кондукторова Т. С., 1972. Антропология древнего населения Украины. М. : МГУ. 155 с.

Мамонова Н. Н., 1986. Опыт применения таблиц В.В. Бунака при разработке остеометрических материалов // Проблемы эволюционной морфологии человека и его рас. М. : Наука. С. 21-33. 
Медникова М. Б., 1998. Описательная программа балловой оценки степени развития рельефа длинных костей // Историческая экология человека. Методика биологических исследований. М. : ИА РАН. С. 161-165.

Пежемский Д. В., 2011. Изменчивость продольных размеров трубчатых костей человека и возможности реконструкции телосложения : дис. ... канд. биол. наук. М. 326 с.

Ражев Д. И., 2009. Биоантропология населения саргатской общности. Екатеринбург : УрО РАН. 492 с.

Ражев Д. И., 1996. Комплекс остеологических признаков всадников // Новое в археологии Южного Урала. Челябинск : Рифей. С. 251-258.

Рохлин Д. Г., 1965. Болезни древних людей. М. ; Л. : Наука. 304 с.

Рыкун М. П., 2013. Палеоантропология Верхнего Приобья эпохи раннего железа (по материалам каменской культуры). Барнаул : Изд-во Алтайского университета. 283 с.

Смаилов Ж. Е., Книссарин Б. А., Хасенова Б. М., Ганиева А. С. 2005. Отчет по теме: Археологическое изучение территории освоения CNPC «Актобемунайгаз» (газопровод Жанажол-Кенкияк) Мугоджарский район Актюнской области. Т. 3 // Архив Института археологии им. А.Х. Маргулана. Ф. 2. Д. 2680. 297 с.

Трофимова Т. А., 1963. Приаральские саки (Краниологический очерк) // Полевые исследования Хорезмийской экспедиции в 1958-1961 гг. : материалы Хорезмской экспедиции. Вып. 6. М. : Наука. С. 221-247.

Фризен С. Ю., 2010. Остеологические (палеоантропологические) материалы из могильника Прохоровка // Яблонский Л.Т. Прохоровка: у истоков сарматской археологии. Материалы и исследования по археологии России. М. : Таус. С. 313-323.

Фризен С. Ю., 2011. Остеологические материалы савромато-раннесарматского времени из могильников покровского микрорайона // Известия Самарского научного центра Российской академии наук. Т. 13, № 3. С. 276 -279.

Чикишева Т. А., 2012. Динамика антропологической дифференциации населения юга Западной Сибири в эпохи неолита-раннего железа. Новосибирск : Изд-во ИАЭТ СО РАН. 468 с.

Чикишева Т. А., 2008. К вопросу о формировании антропологического состава ранних кочевников Тувы // Археология, этнография и антропология Евразии. № 4. С. 120-139.

Чикишева Т. А., 2003. Население горного Алтая в эпоху раннего железа по данным антропологии // Население Горного Алтая в эпоху раннего железа как этнокультурный феномен: происхождение, генезис, исторические судьбы (по данным археологии, антропологии, генетики). Новосибирск : Изд-во СО РАН. С. 63-120.

Beisenov A., Kitov E., 2015. Craniological Materials from Burials of Second Half of the I Millennium BC in Central Khazakstan // Ancient Cultures of the Nothern Area of China, Mongolia and Baikalian Siberia. Huh-Hoto : Scientific press. P. 585-591.

Ćikiševa T.A., 2010. Die paläoantropologischen Materialien // Cugunov K., Parzinger H., Nagler A. Der skythenzeitliche Fursten kurgan Arzan 2 in Tuva. Archaologie in Eurasien. Band 26. Mainz : Verlag Philipp von Zabern. 330 p.

韩康信 [Хань Кансинь], 1993. 丝绸之路古代居民种族人类学研究。[Расово-антропологическое исследование древнего населения на Шёлковом пути]. Урумчи : Народное издательство Синьцзяна. 426 с. (на кит. яз.).

韩康信 [Хань Кансинь], 2010. 丝绸之路古代种族研究。[Исследование древних рас на Шёлковом пути]. Урумчи : Народное издательство Синьцзяна. 532 с. (на кит. яз.).

韩康信, 谭婧泽, 张 帆 [Хань Кансинь, Тань Цзинцзэ, Чжан Фань], 2005. 中国西北地区古代居民 - 族研究。 [Расовые исследования древнего населения Северо-Западного региона Китая]. Шанхай : Изд-во Фуданьского университета. 293 с. (на кит. яз.).

新疆察吾呼：大型氏族墓地发掘报告 [Синьцзян Чауху], 1999. 新疆文物考古研究所编著 [Отчет о раскопках крупного родового могильника]. Пекин : Восток. 416 с. (на кит. яз.).

\section{REFERENCES}

Alekseev V.P., Debets G.F., 1964. Kraniometriya: Metodika antropologicheskikh issledovaniy [Craniometry: Methodology of Anthropological Research]. Moscow, Nauka Publ. 128 p.

Bagashev A.N., 2017. Antropologiya Zapadnoy Sibiri [Anthropology of Western Siberia]. Novosibirsk, Nauka Publ. 408 p.

Bagashev A.N., 2000. Paleoantropologiya Zapadnoy Sibiri: Lesostep v epokhu rannego zheleza [Paleoanthropology of Western Siberia: Forest-Steppe Region in the Early Iron Age]. Novosibirsk, Nauka Publ. 374 p. 
Beysenov A.Z., Ismagulova A.O., Kitov E.P., Kitova A.O., 2015. Naseleniye Tsentralnogo Kazakhstana v I tysyacheletii do n.e. [The Population of Central Kazakhstan in the $1^{\text {st }}$ millennium BC]. Almaty, Institute of Archaeology named after A.Kh. Margulan. $170 \mathrm{p}$.

Beysenov A.Z., Kitov E.P., 2014. Mogilnik tasmolinskoy kultury Taldy II v Tsentralnom Kazakhstane (kraniologicheskiy analiz) [The Taldy II Burial Ground of Tasmoly Culture in the Central Kazakhstan (Craniological Analysis)]. Vestnik Volgogradskogo gosudarstvennogo universiteta. Seriya 4. Istoriya [Science Journal of Volgograd State University. History], no. 4 (28), pp. 71-85. DOI: http://dx.doi.org/10.15688/jvolsu4.2014.4.7.

Bogdanova V.I., Radzyun A.B., 1991. Paleoantropologicheskiye materialy gunno-sarmatskogo vremeni iz Tsentralnoy Tuvy [Paleoanthropological Materials of the Hun-Sarmatian Time from Central Tuva]. Novyye kollektsii $i$ issledovaniya po antropologii i arkheologii. Sbornik muzeya antropologii i etnografii [New Collections and Research of Anthropology and Archaeology. Collection of the Museum of Anthropology and Ethnography], vol. XLIV. Saint Petersburg, Nauka Publ., pp. 55-100.

Buzhilova A.P., 1998. Programma fiksatsii indikatorov mekhanicheskogo stressa. svyazannogo s verkhovoy ezdoy [The Program for Fixing Indicators of Mechanical Stress Associated with Riding]. Istoricheskaya ekologiya cheloveka. Metodika biologicheskikh issledovaniy [Historical Human Ecology. The Methodology of Biological Research]. Moscow, IA RAS, pp. 169-174.

Buzhilova A.P., 2005. Homo sapiens: Istoriya bolezni [Homo Sapiens: Medical History]. Moscow, Yazyki slavyanskoy kultury Publ. $320 \mathrm{p}$.

Buzhilova A.P., 2008. K voprosu o rasprostranenii traditsii verkhovoy ezdy: analiz antropologicheskikh istochnikov [About of the Spread of the Riding Tradition: Analysis of Anthropological Sources]. OPUS: Mezhdistsiplinarnyye issledovaniya v arkheologii [OPUS: Interdisciplinary Research in Archaeology], vol. 6, pp. 110-120.

Velikanova M.S., 1975. Paleoantropologiya Prutsko-Dnestrovskogo mezhdurechia [Paleoanthropology of the Prut-Dniester Region]. Moscow, Nauka Publ. 284 p.

Ginzburg V.V., 1956. Drevneye naseleniye Vostochnykh i Tsentralnykh rayonov Kazakhskoy SSR po antropologicheskim dannym [The Ancient Population of the Eastern and Central Regions of the Kazakh SSR According to Anthropological Data]. Trudy IE AN SSSR [Proceedings of IE USSR Academy of Sciences], vol. XXXIII. Moscow, Academy of Sciences Publishing, pp. 238-298.

Ginzburg V.V., 1961. K antropologii rannikh kochevnikov Vostochnogo Kazakhstana (cherepa V-IV vv. do n.e. iz mogilnika Ust-Bukon) [About Anthropology of the Early Nomads of East Kazakhstan (Skulls of the $5^{\text {th }}$ $4^{\text {th }}$ Centuries BC from the Ust-Bukon Burial Ground)]. Antropologicheskiy sbornik [Anthropological Digest], no. 3. Moscow, Nauka Publ., pp. 82-97.

Ginzburg V.V., Trofimova T.A.. 1972. Paleoantropologiya Sredney Azii [Paleoanthropology of Central Asia]. Moscow, Nauka Publ. 371 p.

Goncharov I.A.. Goncharova N.N., 2016. Programma MultiCan dlya analiza mnogomernykh massivov dannykh s ispolzovaniyem statistik vyborok i parametrov generalnoy sovokupnosti (MultiCan) [MultiCan program for the analysis of multidimensional data arrays using statistics of samples and parameters of the general aggregates]. Svidetelstvo o registratsii prav na PO № 2016610803. 1 p.

Grigor'ev A.P., Kuptsova L.V., 2020. Antropologicheskie materialy rannego zheleznogo veka iz kurgannogo mogil'nika u s. Samorodovo v Orenburzh'e [Anthropological Materials of the Early Iron Age from the Cemetery near the vil. Samorodovo in the Orenburg Region]. Margulanovskie chteniya - 2020: materialy Mezhdunar. arkheol. nauch.-prakt. konf. [Margulanovo Readings - 2020. Materials of the International Archaeological SciencePractical Conference]. Almaty, Khikari, pp. 135-142.

Debets G.F., 1964. Opyt opredeleniya vesa zhivykh lyudey po razmeram dlinnykh kostey [The Experience of Determining the Weight of Living People by the Size of Long Bones]. Trudy VII Mezhdunarodnogo kongressa antropologicheskikh $i$ etnograficheskikh nauk [Proceedings of the VII International Congress of Anthropological and Ethnographic Sciences]. Moscow, Nauka Publ. 11 p.

Zinevich G.P., 1967. Ocherki paleoantropologii Ukrainy [Essays on Paleoanthropology of the Ukraine]. Kiyev, Naukova Dumka Publ. 240 p.

Itina M.A., Yablonskiy L.T., 1997. Saki nizhney Syrdaryi (po materialam mogilnika Yuzhnyy Tagisken) [Sakas of the Lower River Syr-Darya (Materials from the South Tagisken Cemetery)]. Moscow, ROSSPEN Publ. $187 \mathrm{p}$.

Kitov E.P., Beysenov A.Z., 2015. Pervyye kraniologicheskiye dannyye pamyatnikov korgantasskogo tipa Tsentralnogo Kazakhstana [The First Craniological Data of the Korgantas Types Burials in Central Kazakhstan]. 
Vestnik Chelyabinskogo gosudarstvennogo universiteta. Istoriya [Bulletin of the Chelyabinsk State University. History], vol. 64, no. 14 (369), pp. 16-28.

Kitov E.P., Mamedov A.M., 2014. Kochevoye naseleniye Zapadnogo Kazakhstana v rannem zheleznom veke [The Nomadic Population of Western Kazakhstan in the Early Iron Age]. Astana, Branch of the Institute of Archaeology named after A. Kh. Margulan in Astana. 352 p.

Kitov E.P., Tur S.S., Ivanov S.S., 2019. Paleoantropologiya sakskikh kultur Prityanshania (VIII-1-ya polovina II v. do n.e. [Paleoanthropology of Saka Cultures of the Tien Shan (VIII - $1^{\text {st }}$ half of the II century BC]. Almaty, Khikari Publ. $300 \mathrm{p}$.

Kozintsev A.G., 1977. Antropologicheskiy sostav i proiskhozhdenie naseleniya tagarskoy kul'tury [Anthropological Composition and Origin of the Population of Tagar Culture]. Leningrad, Nauka Publ. 142 p.

Konduktorova T.S., 1972. Antropologiya drevnego naseleniya Ukrainy [Anthropology of the Ancient Population of the Ukraine]. Moscow, MSU. 155 p.

Mamonova N.N., 1986. Opyt primeneniya tablits V.V. Bunaka pri razrabotke osteometricheskikh materialov [The Experience of Using Tables V.V. Bunaka in the Development of Osteometric Materials]. Problemy evolyutsionnoymorfologii cheloveka i ego ras [Problems of Evolutionary Morphology of Man and His Races]. Moscow, Nauka Publ., pp. 21-33.

Mednikova M.B. 1998. Opisatelnaya programma ballovoj ocenki stepeni razvitiya relefa dlinnyx kostej [Descriptive Program for Scoring the Degree of Development of the Relief of Long Bones]. Istoricheskaya ekologiya cheloveka. Metodika biologicheskix issledovanij [Historical Human Ecology. The Methodology of Biological Research]. Moscow, IA RAN, pp. 161-165.

Pezhemskiy D.V., 2011. Izmenchivost prodolnykh razmerov trubchatykh kostey cheloveka $i$ vozmozhnosti rekonstruktsii teloslozheniya: dis. ... kand. biol. nauk [Variability of the Longitudinal Dimensions of the Human Tubular Bones and the Possibility of Body Reconstruction. Dr. sci. diss]. Moscow. 326 p.

Razhev D.I., 2009. Bioantropologiya naseleniya sargatskoy obshchnosti [Bioanthropology of the Population of the Sargat Community]. Ekaterinburg, UrB RAS. 492 p.

Razhev D.I., 1996. Kompleks osteologicheskikh priznakov vsadnikov [A Complex of Osteological Signs of Riders]. Novoye v arkheologii Yuzhnogo Urala [New in the archaeology of the Southern Urals]. Chelyabinsk, Rifey Publ., pp. 251-258.

Rokhlin D.G., 1965. Bolezni drevnikh lyudey [Diseases of Ancient People]. Moscow; Leningrad, Nauka Publ. 304 p.

Rykun M.P., 2013. Paleoantropologiya Verkhnego Priobia epokhi rannego zheleza (po materialam kamenskoy kultury) [Paleoanthropology of the Upper River Ob Region of the Early Iron Age (Based on Materials from the Kamenskaya Culture)]. Barnaul, ASU. 283 p.

Smailov Zh.E., Knissarin B.A., Khasenova B.M., Ganiyeva A.S., 2005. Otchet po teme: Arkheologicheskoye izucheniye territorii osvoyeniya CNPC «Aktobemunaygaz» (gazoprovod Zhanazhol-Kenkiyak) Mugodzharskiy rayon Aktyunskoy oblasti [Report: Archeological Study of the "Aktobemunaigas" Development aArea (ZhanazholKenkiyak gas Pipeline) Mugodzhary District of Aktobe Region], vol. 3. Arkhiv Instituta arkheologii im. A.Kh. Margulana. F. 2. D. 2680. 297 p.

Trofimova T.A., 1963. Priaralskiye saki (Kraniologicheskiy ocherk) [Saka of Aral Region (Craniological Essey)]. Polevyye issledovaniya Khorezmiyskoy ekspeditsii v 1958-1961 gg.: materialy Khorezmskoy ekspeditsii [Field Studies of the Khorezm Expedition in 1958-1961. Materials of the Khorezm Expedition], vol. 6. Moscow, Nauka Publ., pp. 221-247.

Frizen S.Yu., 2010. Osteologicheskiye (paleoantropologicheskiye) materialy iz mogilnika Prokhorovka [Osteological (pPaleoanthropological) Materials from the Prokhorovka Cemetery]. Yablonskiy L.T. Prokhorovka: u istokov sarmatskoy arkheologii. Materialy i issledovaniya po arkheologii Rossii [Yablonsky L.T. Prokhorovka: at the Origins of Sarmatian Archaeology. Materials and research on Archaeology of Russia]. Moscow, Taus Publ., pp. 313-323.

Frizen S.Yu., 2011. Osteologicheskiye materialy savromato-rannesarmatskogo vremeni iz mogilnikov pokrovskogo mikrorayona [Osteological Materials of the Sauromatian - Early Sarmatian Time from the Cemeteries of the Pokrovsky microdistrict]. Izvestiya Samarskogo nauchnogo tsentra Rossiyskoy akademii nauk [Bulletin of the Samara Scientific Center of the Russian Academy of Sciences], vol. 13, no. 3, pp. 276-279.

Chikisheva T.A., 2012. Dinamika antropologicheskoy differentsiatsii naseleniya yuga Zapadnoy Sibiri vepokhi neolita-rannego zheleza [Dynamics of Anthropological Differentiation of the Population of the South of Western Siberia in the Neolithic-Early Iron Age]. Novosibirsk, IAE SB RAS. 468 p. 
Chikisheva T.A., 2008. K voprosu o formirovanii antropologicheskogo sostava rannikh kochevnikov Tuvy [On the Formation of the Anthropological Composition of the Early Nomads of Tuva]. Arkheologiya, etnografiya $i$ antropologiya Evrazii [Archeology, Ethnography\&Anthropology of Eurasia], no. 4, pp. 120-139.

Chikisheva T.A., 2003. Naseleniye gornogo Altaya v epokhu rannego zheleza po dannym antropologii [The Population of Altai in the Early Iron Age According to Anthropology]. Naseleniye Gornogo Altaya v epokhu rannego zheleza kak etnokulturnyy fenomen: proiskhozhdeniye. genezis. istoricheskiye sudby (po dannym arkheologii, antropologii, genetiki) [The Population of Altai in the early Iron Age as an Ethnocultural Phenomenon: Origin, Genesis, Historical Fate (According to Archaeology, Anthropology, Genetics)]. Novosibirsk, SB RAS, pp. 63-120.

Beisenov A. Kitov E., 2015. Craniological Materials from Burials of Second Half of the I millennium BC in Central Khazakstan. Ancient cultures of the nothern area of China, Mongolia and Baikalian Siberia. Huh-Hoto, Scientific press, pp. 585-591.

Ćikiševa T.A., 2010. Die paläoantropologischen Materialien. Cugunov K., Parzinger H., Nagler A. Der skythenzeitliche Fursten kurgan Arzan 2 in Tuva. Archaologie in Eurasien, band 26. Mainz, Verlag Philipp von Zabern. $330 \mathrm{p}$.

Khan Kansin, 1993. Sychou chzhi lu guday tszyuymin chzhuntszu zhenleysyuye yantszyu [Racial-Anthropological Study of the Ancient Population on the Silk Road)]. Urumchi, Xinjiang People's Publishing House. 426 p. (in Chinese).

Khan Kansin, 2010. Sychou chzhi lu guday chzhuntszu yantszyu [Research on Ancient Race of Silk Road]. Urumchi, Xinjiang People's Publishing House. 532 p. (in Chinese).

Khan Kansin, Tan Tszintsze., Chzhan Fan, 2005. Chzhungo sibey ditsyuy guday tszyuymin chzhuntszu yantszyu [Racial Studies of the Ancient Population of the Northwest Region of China]. Shankhay, Fudan University Press. 293 p. (in Chinese).

Sintszyan Chaukhu, 1999. Daxing shizu mudi fajue baogao [Report on the Excavation of a Large Clan Cemetery]. Pekin, East Publ. 416 p. (in Chinese).

\section{Information About the Authors}

Egor P. Kitov, Candidate of Science (History), Senior Researcher of Center of Human Ecology, Institute of Ethnology and Anthropology of the Russian Academy of Sciences, Prosp. Lenina, 32A, 119334 Moscow, Russian Federation; Head of Laboratory for Physical Anthropology Research of Kazakhstan, Institute of Archaeology named after A.Kh. Margulan, Prosp. Dostyk, 44 / Shevchenko St., 28, 050010 Almaty, Republic of Kazakhstan, kadet_eg@mail.ru https://orcid.org/0000-0002-0159-3288

Artem P. Grigorev, Junior Researcher, Volga-Ural Center for Paleoanthropological Research, Samara State Social and Pedagogical University, Maxim Gorky St., 65/67, 443099 Samara, Russian Federation, grap9@bk.ru, https://orcid.org/0000-0001-7542-9942

\section{Информация об авторах}

Егор Петрович Китов, кандидат исторических наук, старший научный сотрудник Центра антропоэкологии, Институт этнологии и антропологии им. Н.Н. Миклухо-Маклая РАН, Ленинский просп., 32А, 119334 г. Москва, Российская Федерация; заведующий научно-исследовательской лабораторией палеоантропологического изучения Казахстана, Институт археологии им. А.Х. Маргулана МОН РК, просп. Достык, 44 / ул. Шевченко 28, 050010 г. Алматы, Республика Казахстан, kadet_eg@mail.ru, https://orcid.org/0000-0002-0159-3288

Артем Петрович Григорьев, младший научный сотрудник Волго-Уральского Центра палеоантропологических исследований, Самарский государственный социально-педагогический университет, ул. Максима Горького, 65/67, 443099 г. Самара, Российская Федерация, grap9@bk.ru, https://orcid.org/0000-0001-7542-9942 